\title{
$\mathrm{Ti}-\mathrm{Ni}$ 합금 조성 및 결정구조가 양극산화에 의해 형성하는 산화막 성장거동에 미치는 영향 \\ 김민수 · 김연주 ·김용환* \\ 한국생산기술연구원
}

\section{Effect of Alloying Concentration and Crystal Structure on an Anodic Oxide Layer Formed on Ti-Ni Alloy}

\author{
Min Su Kim, Yeon Joo Kim, and Yong Hwan Kim*
}

Dongnam Technology Service Division, Korea Institute of Industrial Technology, Busan 46744, Republic of Korea

\begin{abstract}
In this work, the growth of nanotubular oxide layers on $\mathrm{Ti}_{1-\mathrm{x}} \mathrm{Ni}_{\mathrm{x}}(\mathrm{x}=0.49,0.498,0.511,0.522,0.525)$ shape memory alloys was investigated. All of the Ti-Ni alloys were fabricated by arc melting process under high vacuum atmosphere. The crystal structure and the growth of the nanotubular oxide layers were investigated by X-ray diffraction (XRD), field-emission scanning electron microscope (FE-SEM) and energy dispersive X-ray spectroscopy attached to a transmission electron microscope (TEM). The electrochemical anodization was carried out at various durations $(5 \mathrm{~min}$ and $20 \mathrm{~min}$ ) and applied voltages $(20 \mathrm{~V}, 35 \mathrm{~V}$ and $50 \mathrm{~V}$ ) at room temperature in ethylene glycol containing $0.06 \mathrm{M} \mathrm{NH}_{4} \mathrm{~F}$ and $1.5 \mathrm{wt} \% \mathrm{H}_{2} \mathrm{O}$. Nanotubular oxide layers were formed on all Ti-Ni alloys by electrochemical anodization, but the morphology of the oxide layers was changed depending on the anodization duration and $\mathrm{Ni}$ concentration of the Ti-Ni alloy substrate. In the case of short duration (5 min), the nanotubular oxide layers were formed on all Ti-Ni alloys by electrochemical anodization, however, the morphology of oxide layer was changed from nanotubular structure to nanopore structure with increasing anodization duration. Moreover, it was cleared that the morphology variation of the nanotubular oxide layers was accelerated with increasing Ni concentration, from 49.0 at\% to 52.5 at\%, which is attributed to the formation of a Ni-rich layer on the Ti-Ni alloy surface by electrochemical anodization.
\end{abstract}

(Received May 30, 2018; Accepted June 30, 2018)

Keywords: shape memory alloy, $\mathrm{Ti}-\mathrm{Ni}$, nanotubular oxide layer, $\mathrm{TiO}_{2}$, anodization

\section{1. 서 론}

Pure $\mathrm{Ti}$ 과 $\mathrm{Ti}$ 합금 표면에 전기화학적 양극산화에 의해 생성되는 나노튜브 형태의 산화막은 Assefpour-Dezfuly et al. 와 Zwilling et al. [1,2]등에 의해 보고된 이후 다양한 밸브금속, 예를 들어 $\mathrm{Zr}[3], \mathrm{Nb}[4], \mathrm{Ta}[5], \mathrm{W}[6], \mathrm{Hf}[7]$ 그리고 이들로 이루어진 합금표면에 나노튜브/나노포러스 형태의 산화막 성장 거동에 대해 많은 연구들이 보고 되었 다 [8-11]. 특히, $\mathrm{Ti}$ 및 $\mathrm{Ti}$ 합금 표면에 생성되는 나노튜브 형태의 산화막은 우수한 에너지 변화 효율, 부식 저항력,

*Corresponding Author: Yong Hwan Kim [Tel: ++82-51-987-2001, E-mail: nanoec@kitech.re.kr] Copyright (C) The Korean Institute of Metals and Materials
생체적합성, 넓은 비표면적을 가지고 있어 광촉매, 태양전 지, 가스센서, 생체재료 분야 등 다양한 분야에서 많은 연 구가 되어 왔다 [12-16]. 이러한 나노튜브 형태의 산화막 성장거동에 영향을 미치는 인자로는 인가전압, 양극산화시 간, 전해액 등이 있으며, 그에 대한 연구가 많이 보고 되 었다 [17-19]. 예를 들어, 나노튜브층 두께는 인가전압 및 양극산화 시간이 증가 할수록 증가하고, 양극산화에 사용 되는 전해액의 종류에 따라 산화막 두께는 크게 변화 한다 고 보고 되었다. 최근 들어 양극산화에 사용되는 금속 또 는 합금의 미세구조나 합금 조성 또한 산화막 성장거동 및 두께에 영향을 미친다고 보고되었다 [20].

Ti-Ni계 형상기업 합금은 우수한 형상기억특성 및 초탄 성 특성으로 인해 다양한 분야에서 많은 연구가 보고 되었 으며, 최근 들어 생채재료 분야에서 주목을 받고 있다 
[21,22]. 하지만, Ti-Ni 합금의 경우, 체내 삽입 후 짧게는 수개월에서 길에는 수십개월 후 합금 표면에 부식이 발생 되고, 이 부식으로 인해 용출 되는 $\mathrm{Ni}$ 이온은 체내에서 염증 반응 및 알레르기 반응뿐만 아니라 기계적 특성 저하 하는 치명적인 문제점이 발생된다고 보고 되었다 [22]. 이 러한 문제점을 개선하기 위해 다양한 표면처리 기술이 연 구 되고 있으며, 그 중 전기화학적 양극산화법은 저렴한 비용으로 합금 표면에 비표면적이 넓은 나노튜브형태의 산화막을 만들 수 있어 많은 연구가 진행 되고 있다 [23,24].

본 연구에서는 다양한 조성의 $\mathrm{Ti}-\mathrm{Ni}$ 합금을 이용하여 미 세구조 및 합금의 $\mathrm{Ni}$ 농도 변화가 $\mathrm{Ti}-\mathrm{Ni}$ 합금표면에 생성되 는 나노튜브 형태의 산화막 성장거동에 미치는 영향과 성 장 메커니즘 규명에 대해 조사 하였다.

\section{2. 실험방법}

본 연구에 사용된 $\mathrm{Ti}_{1-\mathrm{x}} \mathrm{Ni}_{\mathrm{x}}$ 합금 $(\mathrm{x}=0.49,0.498,0.511$, $0.522,0.525$ )은 순도 $99.9 \% \mathrm{Ti}$ 과 순도 $99.0 \% \mathrm{Ni}$ 을 사 용하여 고진공 아크용해법(VAR)을 이용하여 제조하였다. 아크 용해 후 모든 합금은 $1000{ }^{\circ} \mathrm{C}$ 에서 24 시간 균질화 열처리를 실시 하였고, 그 후 냉간압연을 하여 최종두께 2 $\mathrm{mm}$ 로 압연하였다. 제조된 합금은 $\mathrm{X}$-선 회절분석기 $(\mathrm{XRD}$, Philips PW3040/60 X'Pert Pro)를 통해 결정구조 분석을 하였다. 양극산화 시편은 $1.5 \mathrm{~cm} \times 1.5 \mathrm{~cm} \times 2 \mathrm{~mm}$ 크기로 자르고 표면을 기계적 연마 후 아세톤, 에탄올 그리고 증 류수에서 초음파 세척을 하였다. 양극산화는 Ethylene glycol에 $0.06 \mathrm{M} \mathrm{NH}_{4} \mathrm{~F}$ 및 $1.5 \mathrm{wt} \%$ 물을 혼합한 용액을 사용하여 다양한 시간 및 인가전압 에서 실시 하였으며, 양극산화 후 모든 시편은 에탄올 세척을 하였다. 생성된 산화막의 표면, 단면은 FE-SEM(JEOL JSM-7001FA)을 통해 관찰 하였으며, TEM-EDS(Hitachi, HF-2000, EDS - NORAN model 500 analyzer)을 이용하여 산화막과 기 판 표면 성분 분석을 하였다.

\section{3. 결과 및 고찰}

그림 1 은 $\mathrm{Ti}_{1-\mathrm{x}} \mathrm{Ni}_{\mathrm{x}}(\mathrm{x}=0.49,0.498,0.511,0.522,0.525)$ 합금의 XRD 분석 결과이다. 합금의 $\mathrm{Ni}$ 농도가 $50.0 \mathrm{at} \%$ 이하의 경우 에는 상온에서 $\mathrm{B} 19$ ' 마르텐사이트 상이 관찰 되고, 이와 반대로 합금의 $\mathrm{Ni}$ 농도가 $50.0 \mathrm{at} \%$ 이상의 경 우, 상온에서 B2 오스테나이트 상이 관찰되었다. 따라서, 본 연구에서는 합금의 미세구조가 양극산화에 의해 형성되

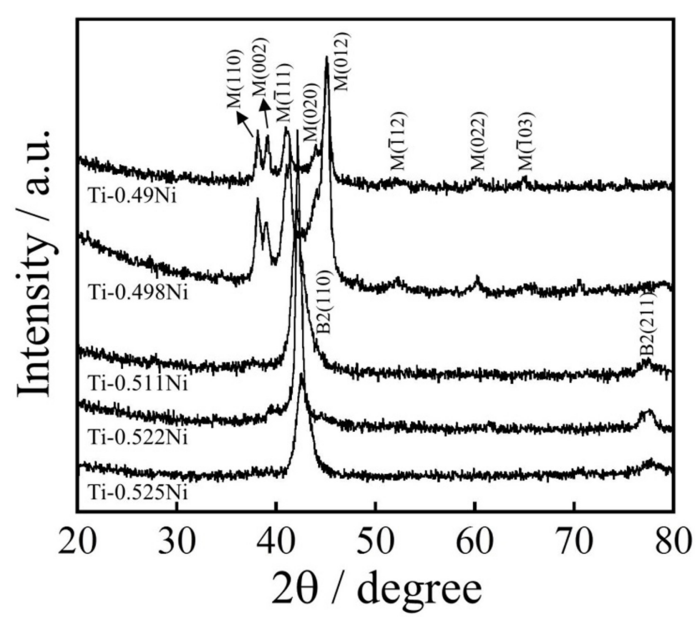

Fig. 1. XRD patterns of Ti-Ni alloys.
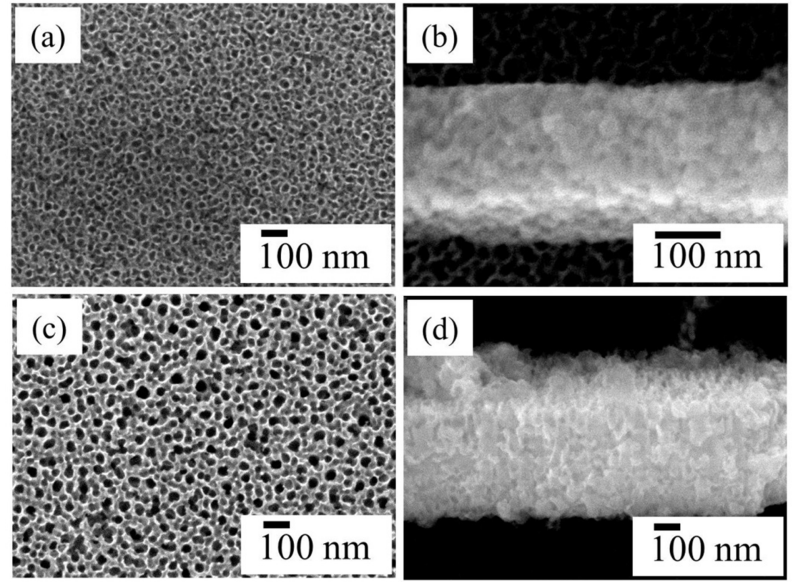

(d)

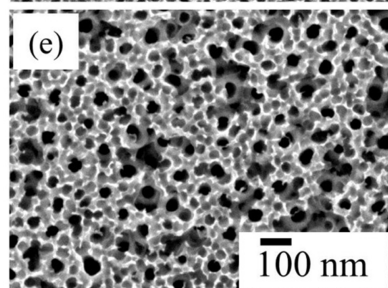

(f)

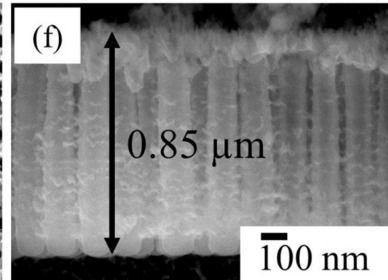

Fig. 2. Top-view and cross-sectional FE-SEM images of oxide layers formed on Ti-0.49Ni alloy at (a, b) $20 \mathrm{~V}$, (c, d) $35 \mathrm{~V}$ and (e, f) $50 \mathrm{~V}$ for $5 \mathrm{~min}$ in ethylene glycol containing $0.06 \mathrm{M} \mathrm{NH}_{4} \mathrm{~F}$ and 1.5 wt $\% \mathrm{H}_{2} \mathrm{O}$.

는 나노튜브 산화막 성장거동에 미치는 영향에 대해서도 조사 하였다.

그림 2는 Ti-0.49Ni 합금 표면에 생성된 산화막의 표면/ 단면 FE-SEM 관찰 결과로서 $(\mathrm{a}, \mathrm{b})$ 는 $20 \mathrm{~V},(\mathrm{c}, \mathrm{d})$ 는 $35 \mathrm{~V},(\mathrm{e}, \mathrm{f})$ 는 $50 \mathrm{~V}$ 에서 각각 5 분동안 양극산화를 실시 한 결과이다. 그림 2(a), (c), (d)에 나타나듯이 인가전압이 

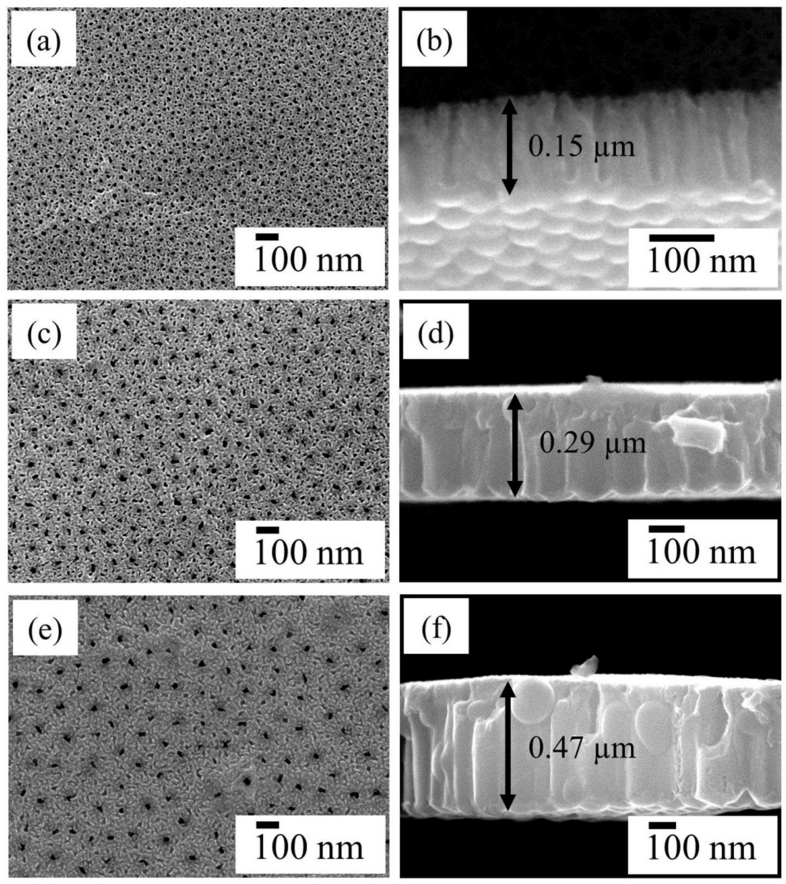

Fig. 3. Top-view and cross-sectional FE-SEM images of oxide layers formed on pure $\mathrm{Ti}$ at $(\mathrm{a}, \mathrm{b}) 20 \mathrm{~V},(\mathrm{c}, \mathrm{d}) 35 \mathrm{~V}$ and $(\mathrm{e}, \mathrm{f}) 50 \mathrm{~V}$ for $5 \mathrm{~min}$ in ethylene glycol containing $0.06 \mathrm{M} \mathrm{NH}_{4} \mathrm{~F}$ and $1.5 \mathrm{wt} \%$ $\mathrm{H}_{2} \mathrm{O}$.

증가 함에 따라 표면 나노 기공의 직경은 증가 하는 것을 알 수 있다. 하지만 단면 관찰결과 $50 \mathrm{~V}$ 에서만 나노튜브형 태의 산화막이 관찰되고, $20 \mathrm{~V}, 35 \mathrm{~V}$ 에서는 나노튜브형태 와 다른 나노포어 형태의 산화막이 형성되는 것으로 나타 났다.

그림 3은 $\mathrm{Ti}-\mathrm{Ni}$ 합금과 비교 하기 위해 동일조건에서 pure Ti을 이용하여 양극산화 후 표면/단면 FE-SEM 관찰 한 결과이다. Pure Ti의 경우 모든 조건에서 나노튜브층이 형성되는 것을 알 수 있었고, 인가전압이 $20 \mathrm{~V}$ 에서 $50 \mathrm{~V}$ 까지 증가 함에 따라 생성되는 산화막의 두께도 증가 하는 것으로 나타났다. 따라서, Ti-Ni 합금의 경우 pure Ti보다 나노튜브 산화막이 형성되는 안정적인 전압 범위가 매우 좁을 것을 알 수 있었다. 또한, 인가전압이 $20 \mathrm{~V}, 35 \mathrm{~V}$ 경 우 생성된 산화막내 $\mathrm{Ti}, \mathrm{Ni}$ 비율은 기판의 농도와 비슷하 게 분석이 되었다. 하지만, $50 \mathrm{~V}$ 경우 산화막내 Ti농도가 $\mathrm{Ni}$ 농도 보다 약 2 배 높게 분석이 되었다. 즉, $\mathrm{Ti}-\mathrm{Ni}$ 합금 의 경우, 인가 전압이 높을수록 $\mathrm{Ti}$ 의 우선적 산화에 의해 나노튜브형태의 산화막을 형성하고 인가전압이 낮을수록 나노튜브형태의 산화막이 형성되지 않고 나노포어 형태의 산화막이 생성되는 것을 알 수 있었다.

따라서 본 연구에서는 Ti-Ni합금 표면에 나노튜브형태의
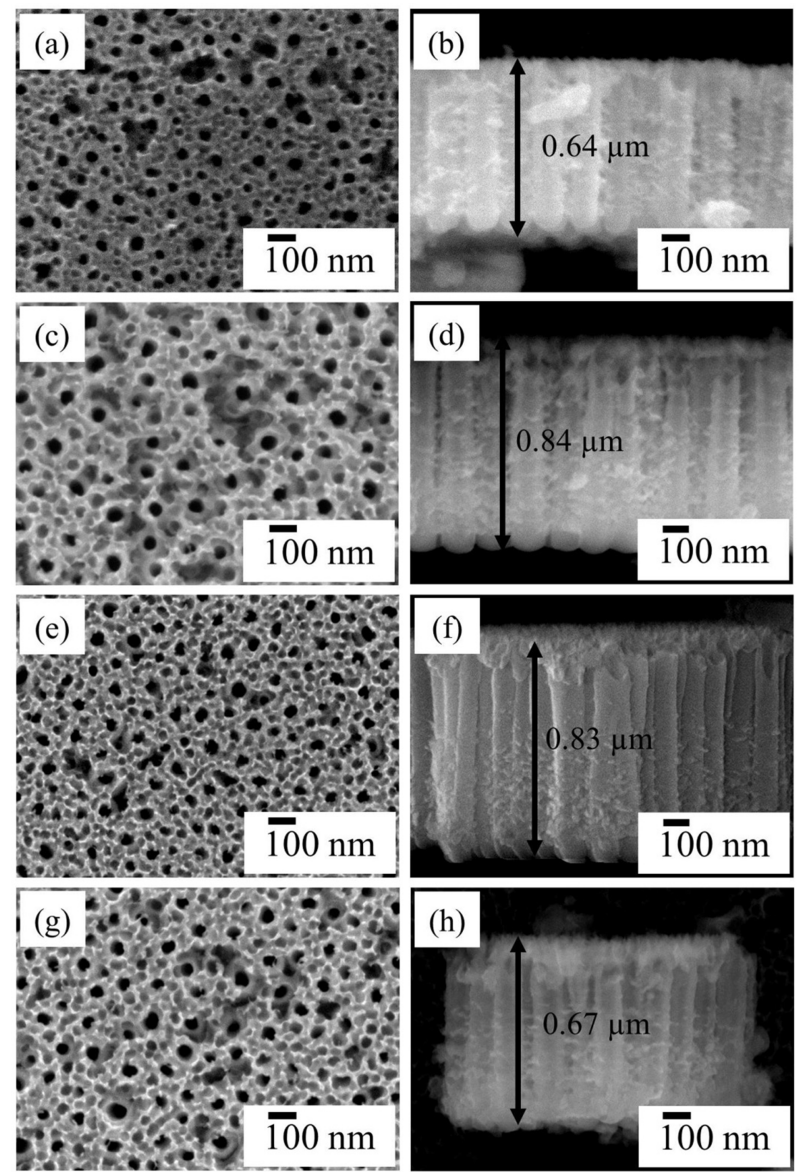

Fig. 4. Top-view and cross-sectional FE-SEM images of oxide layers formed on (a, b) Ti- $0.498 \mathrm{Ni},(\mathrm{c}, \mathrm{d}) \mathrm{Ti}-0.511 \mathrm{Ni}$, (e, f) Ti$0.522 \mathrm{Ni}$ and $(\mathrm{g}, \mathrm{h}) \mathrm{Ti}-0.525 \mathrm{Ni}$ alloy at $50 \mathrm{~V}$ for $5 \mathrm{~min}$ in ethylene glycol containing $0.06 \mathrm{M} \mathrm{NH}_{4} \mathrm{~F}$ and $1.5 \mathrm{wt} \% \mathrm{H}_{2} \mathrm{O}$.

산화막이 안정적으로 형성되는 인가전압 $(50 \mathrm{~V})$ 으로 실험 을 하였다.

그림 4는 (a, b) Ti-0.49 Ni, (c, d) Ti-0.511Ni, (e, f) Ti$0.522 \mathrm{Ni},(\mathrm{g}, \mathrm{h}) \mathrm{Ti}-0.525 \mathrm{Ni}$ 합금을 이용하여 $50 \mathrm{~V} 5$ 분 동안 양극산화 후 생성된 산화막 표면/단면 관찰 결과이다. 그림 4에 나타나듯이 인가전압 $50 \mathrm{~V}, 5$ 분의 경우 합금 조 성에 관계없이 나노튜브 산화막이 형성되는 것을 알 수 있 었고, 생성된 나노튜브층의 두께는 동일조건에서 마르텐사 이트 상보다 오스테나이트상에서 더 두꺼운 나노튜브형태 의 산화막이 형성되는 것을 알 수 있었다. 앞서 그림 1. $\mathrm{XRD}$ 결과에서 나타나듯이 $\mathrm{Ti}-\mathrm{Ni}$ 합금의 경우 $\mathrm{Ni}$ 조성 변화 에 따라 상온에서 마르텐사이트/오스테나이트 2 개의 결정 구조가 존재 하는 것을 알 수 있었다 $(\mathrm{Ni}:<0.5$ - 마르텐 사이트, $\mathrm{Ni}:>0.5$ - 오스테나이트). 이러한 결과로부터, $\mathrm{Ti}-\mathrm{Ni}$ 합금의 경우 결정구조에 따라 생성되는 나노튜브층 의 두께는 차이가 있지만, 생성되는 산화막의 형태는 동일 

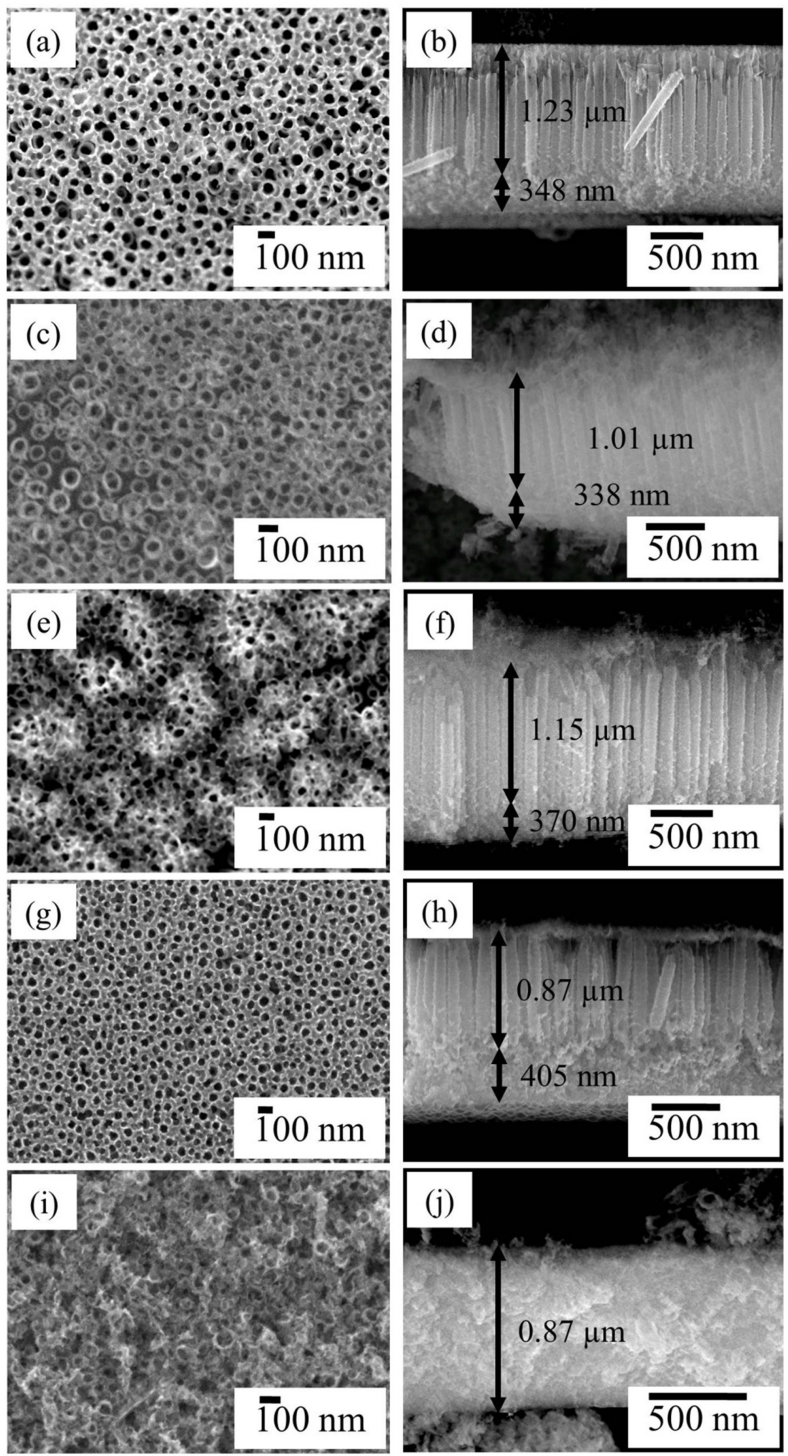

Fig. 5. Top-view and cross-sectional FE-SEM images of oxide layers formed on (a, b) Ti- $0.49 \mathrm{Ni}$, (c, d) Ti- $0.498 \mathrm{Ni},(\mathrm{e}, \mathrm{f}) \mathrm{Ti}-$ $0.511 \mathrm{Ni},(\mathrm{g}, \mathrm{h}) \mathrm{Ti}-0.522 \mathrm{Ni}$ and $(\mathrm{i}, \mathrm{j}) \mathrm{Ti}-0.525 \mathrm{Ni}$ alloy at $50 \mathrm{~V}$ for 20 $\min$

\section{한 것으로 나타났다.}

그림 5는 $(\mathrm{a}, \mathrm{b}) \mathrm{Ti}-0.49 \mathrm{Ni},(\mathrm{c}, \mathrm{d}) \mathrm{Ti}-0.498 \mathrm{Ni},(\mathrm{e}, \mathrm{f})$ Ti-0.511Ni, (g, h) Ti-0.522Ni, (i, j) Ti-0.525Ni 합금을 이용하여 $50 \mathrm{~V}, 20$ 분 동안 양극산화 후 생성된 산화막 표 면/단면 관찰 결과이다. 그림 $5(\mathrm{a}, \mathrm{c}, \mathrm{e}, \mathrm{g})$ 에서 나타나듯 이 Ti-0.49Ni, Ti-0.498Ni, Ti-0.511Ni, Ti-0.522Ni 합금의 경우, 나노튜브 산화막이 관찰 되었다. 하지만 그림 $5(\mathrm{~b}$, $\mathrm{d}, \mathrm{f}, \mathrm{h}$ )에서 나타나듯이 나노튜브층 바로 밑부분에서 나노 포어 형태의 산화막이 형성되는 것을 알 수 있다. 이는 그 림 6 에서 명확히 확인 할 수 있다. 또한 $\mathrm{Ti}-0.525 \mathrm{Ni}$ 에서는
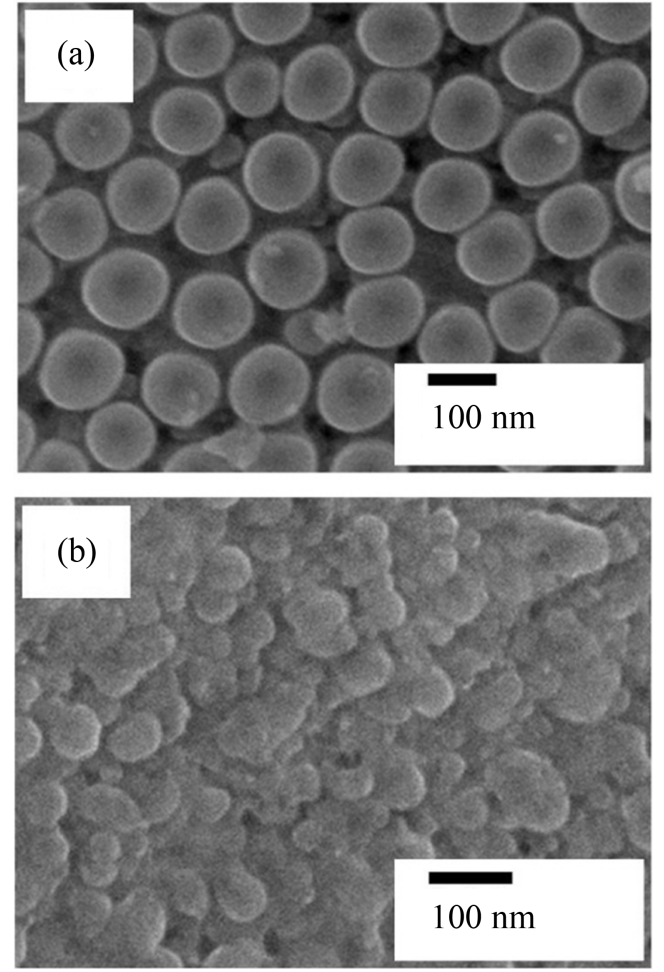

Fig. 6. Bottom-view FE-SEM images of oxide layers formed on Ti$0.49 \mathrm{Ni}$ alloy at $50 \mathrm{~V}$ for (a) $5 \mathrm{~min}$ and (b) $20 \mathrm{~min}$.

산화막 전체가 나노튜브형태와는 다른 나노포어 형태의 산 화막이 형성되는 것을 알 수 있었다. 즉, Ti-Ni합금의 경우 첨가되는 $\mathrm{Ni}$ 조성이 증가 할수록 나노튜브 형태의 산화막 에서 나노포어 형태의 산화막으로 산화막 형태가 바뀌는 것이 가속화되는 것을 알 수 있었다.

그림 6 은 $\mathrm{Ti}-0.49 \mathrm{Ni}$ 합금 표면에 생성된 산화막의 바닥을 관찰한 결과로서 그림 6 (a)는 $50 \mathrm{~V}, 5$ 분, 그림 6 (b)는 $50 \mathrm{~V}, 20$ 분간 양극산화를 실시한 결과 이다. 그림 6 에서 나타나듯이 양극산화 시간이 5 분에서 20 분으로 증가 함에 따라 산화막 바닥부분의 형태 또한 원형(그림 6 (a))에서 불균일한 형태(그림 6 (b))로 변화하는 것을 알 수 있다. 이런 유사한 거동은 합금의 $\mathrm{Ni}$ 조성에 관계없이 모든 시편 (Ti-0.49Ni，Ti-0.498Ni，Ti-0.511Ni，Ti-0.522Ni，Ti$0.525 \mathrm{Ni}$ )에서 관찰 되었다.

본 연구에 사용된 $\mathrm{Ti}-\mathrm{Ni}$ 합금의 경우, 양극산화에 의해 생성되는 산화막의 형태는 양극산화 시간 및 합금 조성이 증가 함에 따라 나노튜브형태에서 나노포어 형태로 산화막 의 형태가 변화하는 것으로 나타났다. 이러한 성장 거동을 규명하기 위해 Ti-0.49Ni합금을 이용하여 양극산화 후 TEM-EDS분석 하였다. 


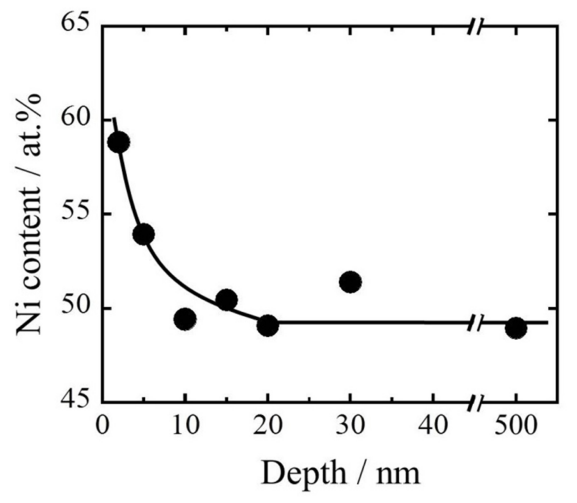

\begin{tabular}{|c|c|c|}
\hline & Ti / at.\% & Ni / at.\% \\
\hline Oxide layer & 68.68 & 31.32 \\
\hline \multicolumn{3}{|c|}{ Depth prof ling from alloy surface } \\
\hline $2 \mathrm{~nm}$ & 41.18 & 58.82 \\
\hline $5 \mathrm{~nm}$ & 46.05 & 53.95 \\
\hline $10 \mathrm{~nm}$ & 50.57 & 49.43 \\
\hline $15 \mathrm{~nm}$ & 49.54 & 50.46 \\
\hline $20 \mathrm{~nm}$ & 50.92 & 49.08 \\
\hline $30 \mathrm{~nm}$ & 48.60 & 51.40 \\
\hline $500 \mathrm{~nm}$ & 51.04 & 48.96 \\
\hline
\end{tabular}

Fig. 7. Depth distribution of $\mathrm{Ti}$ and $\mathrm{Ni}$ content in Ti-0.49Ni alloy substrate from the interface between the alloy substrate and the anodic oxide layer.

그림 7 은 $\mathrm{Ti}-0.49 \mathrm{Ni}$ 합금을 이용하여 $50 \mathrm{~V}$ 에서 20 분간 양극산화 후 합금 표면을TEM-EDS분석한 결과이다. 그림 7 에서 나타나듯이 합금 표면에서 $(0 \mathrm{~m})$ 약 $10 \mathrm{~nm}$ 이상 에 서는 합금 조성과 비슷한 $\mathrm{Ni}$ 농도가 분석되었지만, 표면에 서 약 $10 \mathrm{~nm}$ 이내 에는 합금 조성인 0.49 보다 많은 $\mathrm{Ni}$ 농 도가 검출 되었다. 이러한 결과는 양극산화 가 진행되는 동안 $\mathrm{Ti}$ 이 우선적으로 산화되어 $\mathrm{Ti}$ 과잉의 산화막을 생성하 고, 이와 동시에 $\mathrm{Ni}$ 은 상대적으로 산화가 되지 않아 합금 표면에서 $\mathrm{Ni}$ 과잉층을 형성하는 것을 의미한다. 이러한 산 화물과 합금 계면 사이에 합금 원소의 축적되는 현장은 다 른 연구에서도 보고 되었는데 [25,26], Pelton et al.은 $\mathrm{Ti}-\mathrm{Ni}$ 합금이 고온에서 산화될 때 $\mathrm{Ti}$ 이 우선적으로 산화되 어 $\mathrm{Ti}$ 과잉의 산화막이 형성되고, 합금표면에는 $\mathrm{Ni}$ 과잉층이 형성된다고 보고 하였다 [25]. 또한, Al-W합금에서도 양극 산화 동안 산화막과 합금 계면 사이에 $\mathrm{W}$ 과잉층이 형성된 다고 보고 하였다 [26]. 또한 그림 5에서도 나타나듯이 합 금 $\mathrm{Ni}$ 농도가 높을수록 나노포어 형태의 산화막은 빠르게 생성되는 것을 알 수 있었다. 이러한 결과에서 알 수 있듯 이, Ti-Ni 합금의 경우, 양극산화 시간이 증가함에 따라 합 금 표면에 $\mathrm{Ni}$ 과잉층이 형성이 되고 이렇게 생성된 $\mathrm{Ni}$ 과 잉층은 나노튜브형태의 산화막 형성을 억제하여 나노튜브 층 밑부분에 나노포어 형태의 산화막이 형성되는 것을 알 수 있었다(그림 5 (b), (d), (f), (h)). 또한 양극산화 시간 을 길게 하면(1시간) 나노포어 형태의 산화막이 형성되는 것을 알 수 있었다. 이러한 현상은 양극산화 시간이 증가 함에 따라 합금표면에 형성된 Ni과잉층(약 $10 \mathrm{~nm})$ 에 의해
나노튜브 형태의 산화막 형성이 억제됨과 동시에 양극산화 초기(5분)에 생성된 나노튜브형태의 산화막이 전부 용해된 것에 기인한다.

\section{4. 결 론}

본 연구에서는 5종류의 Ti1-xNix ( $\mathrm{x}=0.49,0.498$, $0.511,0.522,0.525)$ 합금을 이용하여 양극산화법에 의해 생성되는 산화막 성장거동에 관해 조사 하였다. Ti-Ni 합 금의 경우 pure $\mathrm{Ti}$ 에 비해 합금을 구성하는 $\mathrm{Ti}$ 의 우선적 산화에 의해 나노튜브 형태의 산화막이 형성되는 안정적인 전압 범위가 매우 좁을 것을 알 수 있었다. 또한 양극산화 시간이 증가 함에 따라 $\mathrm{Ti}$ 이 우선적으로 산화되어 $\mathrm{Ti}$ 과잉 의 나노튜브형태의 산화막을 형성하고, 이와 동시에 상대 적으로 $\mathrm{Ni}$ 은 산화되지 않아 합금표면에 $\mathrm{Ni}$ 과잉층이 형성 되는 것을 알 수 있었다. 이렇게 형성된 $\mathrm{Ni}$ 과잉층은 나노 튜브형태의 산화막 성장을 억제 하고 나노포어 형태의 산 화막을 형성하는 것을 알 수 있었다. 또한 합금의 $\mathrm{Ni}$ 농도 가 증가 할수록 양극산화 동안 $\mathrm{Ni}$ 과잉층의 형성이 빨라지 고 결과적으로 나노튜브에서 나노포어 형태로 산화막 형태 변화가 빠르게 일어나는 것을 알 수 있었다.

\section{REFERENCES}

1. M. Assefpour-Dezfuly, C. Vlachos, E. H. Andrews, J. Mater. Sci. 19, 3626 (1984). 
2. V. Zwilling, E. Darque-Ceretti, A. Boutry-Forveille, D. David, M. Y. Perrin, and M. Aucouturier, Surf. Interface Anal. 27, 629 (1991).

3. W. J. Lee and W. H. Smyrl, Electrochem. Solid State Lett. 8, B7 (2005).

4. I. Sieber, H. Hildebrand, A. Friedrich, and P. Schmuki, Electrochem. Commun. 7, 97 (2005).

5. I. Sieber, B. Kannan, and P. Schmuki, Electrochem. SolidState Lett. 8, J10 (2005).

6. N. R. de Tacconi, C. R. Chenthamarakshan, G. Yogeeswaran, A. Watcharenwong, R. S. de Zoysa, N. A. Basit, and K. Rajeshwar, J. Phys. Chem. B 110, 25347 (2006).

7. H. Tsuchiya and P. Schmuki, Electrochem. Commun. 7, 49 (2005).

8. S. H. Jang, H. C. Choe, Y. M. Ko, and W. A. Brantley, Thin Solid Films 517, 5038 (2009).

9. D. Ding, C. Ning, L. Huang, F. Jin, Y. Hao, S. Bai, Y. Li, M. Li, and D. Mao, Nanotechnol. 20, 305103 (2009).

10. H. Tsuchiya, T. Akaki, Y. Koizumi, Y. Minamino, and S. Fujimoto, Electrochem. Commun. 26, 117 (2013).

11. E. H. Jung, and B. Y. Jeong, Korean J. Met. Mater. 51, 807 (2013)

12. J. G. Yu, G. P. Dai, and B. Cheng, J. Phys. Chem. C 114, 19378 (2010).

13. G. K. Mor, K. Shankar, M. Paulose, O. K. Varghese, and C. A. Grimes, Nano Lett. 6, 215 (2006).

14. H. F. Lu, F. Li, G. Liu, Z. Chen, D. Wang, H. Fang, G. Lu, Z. Jiang, and H. Cheng, Nanotechnology 19, 405504 (2008).
15. S. Berger, A. Ghicov, Y. C. Nah, and P. Schmuki, Langmuir 25, 4841 (2009).

16. K. Das, S. Bose, and A. Bandyopadhyay, J. Biomed. Mater. Res. A 90, 225 (2009).

17. Y. Lai, L. Sun, Y. Chen, H. Zhuang, Ch. Lin, and J. W. Chin, J. Electrochem. Soc. 153, D123 (2006).

18. J.M. Macak and P. Schmuki, Electrochim. Acta 52, 1258 (2006).

19. J. M. Macak, L. V. Taveira, H. Tsuchiya, and K. Sirotna, $P$. Schmuki, J. Electroceram. 16, 29 (2006).

20. C. P. Ferreira, M. C. Goncalves, R. Caram, R. Bertazzoli, and C. A. Rodrigues, Appl. Surf. Sci. 285, 226 (2013).

21. S. Miyazaki, K. Otsuka, and C. M. Wayman, Acta Metall. 7, 1885 (1989).

22. J. Ryhanen, Doctoral Thesis. pp. 31-40, Oulu University, Oulu (1999).

23. Z. Li, D. Ding, Q. Liu, and C. Ning, Sensors 13, 8393 (2013).

24. R. Hang, X. Huang, L. Tian, Z. He, and B. Tang, Electrochim. Acta 70, 382 (2012).

25. A. R. Pelton, A. Mehta, L. Zhu, C. Trépanier, V. Imbeni, S. Robertson, M. Barney, A. Minor, Inorganic Materials, in: J. M. Howe, D. E. Laughlin, J. K. Lee, U. Dahmen, W. A. Soffa (Eds.), Phase Transformations in Novel Systems of Special Materials 2, 1029 (2005).

26. H. Habazaki, K. Shimizu, P. Skeldon, G. E. Thompson, and G. C. Wood, J. Electrochem. Soc. 143, 2465 (1996). 